\title{
Winery website loyalty: the role of sales promotion and service attributes
}

\begin{tabular}{|r|l|}
\hline Journal: & International Journal of Wine Business Research \\
\hline Manuscript ID & IJWBR-01-2017-0003.R2 \\
\hline Manuscript Type: & Research Article \\
\hline Methods: & $\begin{array}{l}\text { mobile commerce, wine purchase, mobile phone, website loyalty, sales } \\
\text { promotion, service attributes }\end{array}$ \\
\hline Topics: & $\begin{array}{l}\text { Customer loyalty, Canada, France, Germany, South Africa, United States of } \\
\text { America }\end{array}$ \\
\hline
\end{tabular}

\section{SCHOLARONE \\ Manuscripts}




\section{Winery website loyalty: \\ The role of sales promotion and service attributes}

Purpose: toward buying wine on mobile phones and m-commerce website loyalty by examining a) the mediating role of sales promotion and b) the moderating role of service attributes of the m-commerce websites in influencing the mediation.

Design/methodology/approach: A total of 3,318 completed surveys were collected. Drawing on a large non-probability criterion-based purposive sample across six countries (France, Germany, Greece, South-Africa, United States and Canada) mediation analysis was performed to examine hypothesized relationships.

Findings: Results show that sales promotion mediates the relationship between feelings towards buying wine on mobile phones and m-commerce website loyalty. Moderated mediation reveals that the indirect pathways (sales promotion) through which feelings towards buying wine over mobile exert its effect on m-commerce website loyalty is dependent on the value of service (wine delivery) attributes of the website. The results demonstrate that sales promotion and service are of paramount importance to wineries and wine marketers.

Research implications/limitations: Wine producers and retailers should consider the use of sales promotion to enhance sales and loyalty to m-commerce websites.

Practical implications: Wine producers and retailers should consider use sales promotion (such as SMS or push notifications) to enhance sales and influence consumer feelings and hence their loyalty.

Originality/value: Wine $\mathrm{m}$-commerce studies are limited, especially with an international perspective comparing 6 different countries: 3 from the old world (such as France, Germany and Greece) and 3 from the New World (North America with USA and Canada; and SouthAfrica). Altogether those 6 countries represent around $40 \%$ of the world consumption.

\section{INTRODUCTION}

With more than 139 million results produced by Google when the words "purchase" and "wine" are searched together, it is clear there is enormous competition for wine producers or retailers on the Internet. According to eMarketer (2015), total retail sales are growing slowly but steadily in the US. Although e-commerce is growing more quickly than offline sales, ecommerce is expected to rise only slightly as a share of the total, from $7.2 \%$ this year to $9.8 \%$ 
by 2019 . Mobile e-commerce is an even smaller proportion, accounting for a tiny $1.6 \%$ of all retail sales, and by 2019 , its share is projected to be $2.7 \%$ of total sales. Mobile transactions are increasing exponentially, with reports indicating that the worldwide mobile payment volume in 2015 was 450 billion U.S. dollars and is expected to surpass 1 trillion U.S. dollars in 2019 (Statista, 2016). This massive change summarizes the shift from a sedentary online consumer, shopping on the Internet, to a ubiquitous consumer, who uses smartphones and tablets to visit merchant websites. This means that customers can be reached directly on their mobile devices anywhere, anytime, offering an unprecedented level of access to consumers for marketers. M-commerce (mobile commerce) occurs by means of wireless devices, mainly smartphones and tablets (Huang et al., 2015; Shaikh \& Gupta, 2014; Wu \& Wang, 2005). Mcommerce shopping behaviors vary across countries (Pelet et al., 2016), reflecting variations in access to information and internet shopping habits of different age cohorts (Pelet \& Lecat, 2014). M-commerce is expected to capture more wine shopping online irrespective of age of the consumer. Understanding consumers' perceptions of m-commerce and the factors that might positively and negatively affect these perceptions is thus important for wine marketers.

The subject of the mobile interface connecting the user to an online store (e.g. smartphones or tablets) remains an important subject that has received limited research attention. Devices, such as smartphones, tablets and netbooks are recognized as being of great consequence for online consumer behavior, as they offer more utilitarian and hedonic benefits than notebooks or other devices (Ha \& Park, 2013). Limited research on the topic of loyalty towards websites selling wine is evident and the reasons why customers come back to websites and buy wine are not theoretically grounded limiting understanding. Retailers who understand how to use these latest digital distribution channels to help customers find, buy and use the products they sell, will be rewarded with loyal customers who spend more and advocate the brand (Tubaro et al., 2012).

Growth in mobile device usage, specifically of smartphones is favouring the surge in mobile shopping (Lenhart et al., 2011). Lee et al. (2015) propose that factors such as mobile phone simplicity and interactivity are enhancing the user experience, leading to positive perceptions about using a mobile phone for m-commerce. Some recent research has focused on the adoption, acceptance and use of $\mathrm{m}$-commerce; the utilitarian and hedonic factors that might influence it (Li et al., 2012); and its customer satisfaction (Choi et al., 2008; Trevinal \& Stenger, 2014). Lee et al. (2015) also examined customers' positive involvement as a 
precursor to website loyalty finding that distrust mediates customer perceptions of various web features in the process of building customer loyalty.

This paper examines the relationship between feelings toward buying wine on mobile phones and loyalty toward the wine producer/retailers' m-commerce websites. Drawing on the literature this study proposes that sales promotion mediates the relationship between feelings toward buying wine on mobile phones and loyalty toward m-commerce websites, and that the indirect effect of sales promotion is dependent on service attributes of the wine producer/retailer's m-commerce website. The paper is organised as follows. First, we conceptualise online sales promotion, service delivery attributes of m-commerce websites, the affective state of buying wine on mobile phones and m-commerce website loyalty. We then develop the theoretical model and hypotheses. Finally, results and analyses are interpreted and the theoretical contributions and practical implications of the study discussed.

\section{DEVELOPMENT OF THE THEORETICAL FRAMEWORK}

This section starts with a discussion of the key constructs being investigated i.e. online sales promotion, feelings towards buying wine on mobile phones, m-commerce website loyalty and service attributes on websites, and then develops the theoretical model.

\subsection{Online sales promotion}

Online wine sales currently represent less than $5 \%$ of total wine sales in developed countries (Higgins et al., 2014), although growth in online sales is expected. In a study across numerous industries, the most frequently used online advertising methods were email ads, social media and webpages (Leeflang et al., 2014). Of the various promotional tools, online ads have been found to have a significant positive effect on sales (Peng et al., 2014), alcohol consumption and intentions to purchase alcohol (see Lobstein et al., 2017). Marketing promotions including limited time offers and discounts have been shown to increase online purchases (see Chan et al., 2017). In the US wine industry specifically, Thach et al. (2014) found that online newsletters, social media, and electronic word-of-mouth were the most important online sales promotion tools. Online sales promotion offers practical advantages (temporal and spatial), financial advantages (through price comparison), and hedonic ways of 
consuming (Eroglu et al., 2001). Thus, positive feelings towards buying wine via mobile phones could be stronger when sales promotion is present on the sellers' website.

\subsection{Feelings toward mobile-wine purchasing}

When people are feeling positive, they tend to have more favourable expectations for the future (Masters \& Wyndol, 1976). We expect that if consumers have positive feelings about buying wine using m-commerce they will be more likely to make purchases from a wine firm or seller's website. This is consistent with Wu et al. 's (2008) study suggesting that emotions are a significant predictor of purchase intention, especially in the wine industry where wine itself can offer high emotional utility (Dressler, 2016). Further evidence on the role that emotions play in online purchasing is summarised in Chan et al. (2017). Chan et al. (2017) identified numerous studies examining affective reactions and concluded that consumers indulge in online impulse-buying responses when they experience positive affective reactions, such as pleasure and arousal. Taken together, literature summarised in the Chan et al. (2017) review suggests that pleasure motivates impulse buying, and arousal mobilizes the process indicating the importance of emotion in $\mathrm{m}$-wine purchasing.

\subsection{M-commerce website loyalty}

Previous research has suggested that customer loyalty should be the consequence of perceived value, customer satisfaction, trust and habit (Lin \& Wang, 2006). Online loyalty or e-loyalty has been defined as a consumer's intention to buy from or visit a website again (Cyr et al., 2006; Flavián et al., 2006; Yoon et al., 2008). According to Dressler (2016) “wine consumers increasingly explore new wines, alternative wineries, and innovative offerings" and the propensity to seek variety limits customer loyalty (Schipperges, 2013). Although wineries are aware of the need to react to customer changes the degree of interaction remains low (Jungbauer, 2012), which is surprising given current technical capabilities. As noted by Osuna Ramírez et al. (2017) loyalty has been studied from two perspectives, namely stochastic and deterministic. According to stochastic views a behavioural view is taken and loyalty is considered as repeat purchase (behavioural loyalty). This is in contrast to the deterministic view termed attitudinal loyalty, which holds a more relational viewpoint suggesting that loyalty is a function of a consumer's commitment to a product which in turn can lead to referral behaviour. Buying intentions provide a measure of attitudinal loyalty 


\subsection{Service attributes of wine websites}

In our conceptualisation, we have taken into account that wine is heavy, fragile and difficult to deliver, requiring special care from transporting companies. It is important for e-commerce orders to attain on-time delivery in order to maintain customer trust and satisfaction (Pelet et al., 2016). Bressolles and Durrieu (2011) suggest that the main components of e-service quality are information, ease of use, and the design, reliability and security of the website. Consistent with these components, we conceptualise that the service delivery attributes of a wine website include follow-up communication, on-time delivery, tracking service and low delivery charges.

Drawing on previous literature (Mehrabian and Russell, 1974) we developed a moderated mediation model that examines sales promotion as the mediating mechanism and website service attributes as the variable moderating the effect of feelings toward mobile wine buying on m-commerce website loyalty. This proposition is based on Mehrabian and Russell's (1974) PAD theory which describes how the "Feelings towards buying wine via mobile phone" have an effect on the "Importance of sales promotions" and on the "Mobile website loyalty". According to PAD "Online service (wine delivery) attributes of the winery website" will have a moderating effect on the link between the "Feelings towards buying wine via mobile phone" and the "Mobile website loyalty". The moderator explains when or under what conditions a particular effect can be expected whereas a mediator explains how or why a particular effect or relationship may occur. The three most commonly used measures of 
emotions are: pleasure, arousal and dominance (PAD) (Sørensen, 2008; Koufaris, 2002), which are normally related to the environmental stimuli component in m-commerce (Kaikkonen, 2012).

Figure 1: The role of sales promotion and service attributes

\begin{tabular}{|l|l|}
\hline Figure 1 about here & $\mathrm{X}=$ Feelings towards buying wine via mobile phone \\
$\mathrm{Y}$ & $=$ Mobile website loyalty \\
$\mathrm{Mi} \quad=$ Importance of Sales Promotions \\
$\mathrm{W} \quad=$ Online service (wine delivery) attributes of the \\
winery website
\end{tabular}

Based on relevant literature we propose:

H1: The relationship between feelings toward buying wine via mobile phone and $\mathrm{m}$-website loyalty is mediated by sales promotion.

H2: The relationship between feelings towards buying wine via mobile phone and $\mathrm{m}$ commerce website loyalty will be stronger when online service (wine delivery) attributes of the winery website is higher.

H3: The relationship between feelings toward buying wine via mobile phone and m-website loyalty is mediated by sales promotion and this effect will be stronger when online service (wine delivery) attributes of the winery website is higher.

\section{RESEARCH METHOD}

The study was implemented on the Internet in five countries using a questionnaire embedded on a landing page designed using responsive web design (i.e. adaptable to all screen sizes and devices) in order to facilitate the answering of questions on any type of device (from smartphones to laptops). The online survey was offered in a paper version for administration in the US where data were collected in person. Data was collected between the months of October and December 2016 using both personal and online questionnaires. Non-probability, criterion-based purposive sampling was used because it allowed the researchers to intentionally select participants who have experience with the central phenomenon being 
explored (Hair et al., 2009). Online surveys were distributed on social media and via emails. The questionnaire was structured into three sections: (1) wine purchasing and consumption, (2) m-wine purchasing, and (3) personal information.

\subsection{Sample and Data collection}

A total of 3318 completed surveys were collected from respondents in six countries (France, Germany, Greece, South Africa, United States and Canada). These countries have been chosen for multiple reasons: some of them are major global wine producing countries (France, Germany, South Africa, United States), others are not wine producers, and others are heavy wine drinkers (Greece). All countries represent $40 \%$ of global wine consumption.

In this study, the central phenomenon under investigation is $\mathrm{m}$-wine purchasing. The sample was initially screened for legal drinking age, ownership of a smartphone for online access and online wine behaviours. Specifically, we screened to ensure participants were members of a wine club or liked a fan page dedicated to wine. The final sample dataset consisted of 2754 valid respondents after applying selection criteria.

\subsection{Survey Instrument}

To measure the feelings with regards to buying wine using a mobile phone, we adapted Mehrabian and Russell's (1974) PAD scale. Participants responded to questions assessing their feelings, using bi-polar items with anchors including harmful/beneficial, unpleasant/pleasant, bad/good, worthless/valuable, and unenjoyable/enjoyable on a five-point semantic differential scale, where 1 represented "negative feelings" and 5 "positive feelings". We used the PAD scale due to its consistently high reliability (Valdez \& Mehrabian, 1994).

Website loyalty has been defined in terms of usability, which includes the promptness with which the system can be used (Davis, 1989), and its user friendliness, ease of navigation and organization (Parasuraman et al., 2005). In our conceptualization, m-commerce website loyalty is the extent to which a consumer is going to visit the m-commerce website to get the information he or she needs, and the extent to which a visitor has the behavioural tendency to regularly visit a wine website. This construct was measured with four items using a 5-point Likert type scale, where 1 was "strongly disagree" and 5 was "strongly agree". Items 
included: I know which website I should visit to get the information I need; I am loyal to a particular website; I can find my favorite website address without much effort; I can immediately recognize my favorite website address if it is presented among other addresses.

The service attributes of an m-commerce website are defined as the extent to which such attributes encourage buying wine on a mobile phone. We asked respondents to rate items on a Likert-type scale where 1 denoted "very unimportant" and 5 denoted "very important". A total of four service attribute measures were used: on-time delivery; quality of the wine; tracking your online purchase and low delivery charges. The assumption is that quality of wine and on-time delivery influence website revisits while being able to track orders online assures consumers and builds confidence in the transaction exchange. Yoon (2002) found that both trust and satisfaction positively influenced website revisits. We asked participants to rate the importance of online sales promotion when buying wine through mobile phones, measured on a 5-point scale where 1 denoted "unimportant" and 5 denoted "important".

In our study, m-commerce website loyalty is the dependent variable. The independent variable consisted of consumer feelings toward buying wine using mobile phones. Service (wine delivery) attributes and sales promotion efforts entered the model as moderating and mediating variables respectively. We deemed it necessary to control for wine expertise and drinking habits on the hypothesised relationship (moderated mediation). The rationale behind controlling these factors stem from argument that a high level of wine expertise correlates with drinking habits, volume and the value of purchase (Trent \& Bastian, 2007).

\subsection{Scale Validation}

Using Preacher et al.'s (2007) procedure, we report a moderated mediation test of our model. The most commonly used test for internal consistency is Cronbach's alpha (Cronbach, 1951) and values for the independent and mediating and moderating factors ranged between .69 and .89 on this test. Rossiter (2002) suggests the importance of expert judgement for the face validity of the research instrument. Accordingly, twelve experts from marketing and information science fields critically evaluated all the items in the research instrument to assess content validity, representativeness, dimensionality, comprehensibility and unambiguity. 
Table 1 about here

To analyse unidimensionality, exploratory factor analysis (EFA) was employed using SPSS, version 20. This was followed by confirmatory factor analyses (CFA) for validation of the measurement model. All of the fit indices $(\mathrm{RMR}=0.03, \mathrm{GFI}=.99, \mathrm{AGFI}=.98, \mathrm{NFI}=.98$, $\mathrm{TLI}=.98, \mathrm{CFI}=.99 \mathrm{RMSEA}=0.03)$ were in the acceptable range as suggested by Bentler (1992). In addition, we found all the individual factor loadings to be highly significant, giving support for convergent validity (Gerbing \& Anderson, 1988). We calculated the Cronbach alpha coefficient, composite factor reliability, and average variance extracted for each of the scales and the values were in the desirable range except for online service (wine delivery) attributes, which fell just below the cut-off criteria. We made the decision to retain service (wine delivery) attributes for mobile wine purchase in our analysis on theoretical grounds (Cronbach's alpha: 0.69). We also tested for alternate models and found the original models to be better than all the constrained models. Table 2 shows that our measures have the required construct validity.

\section{Table 2 about here}

\section{RESULTS \& DISCUSSION}

We used hierarchical multiple regressions to test Hypothesis 1 and hierarchical moderated regression to test Hypothesis 2. In all analyses we entered the control variables of wine expertise and drinking habit. All variance-inflation factors in our regression were below 2; and none of the bivariate correlations had high coefficients, suggesting that multicollinearity is not an issue in our analysis.

\subsection{Mediation: the role of sales promotion (H1)}

Preacher et al. 's (2007) process was used to investigate the first hypothesis (H1) suggesting that the importance of sales promotion mediates the relationship between feelings towards buying wine on mobile phone and m-commerce website loyalty. Path analysis indicated feelings towards buying wine on mobile and online sales promotion was positive and statistically significant $(\beta=.17, \mathrm{p}<.001)$. The positive correlation suggests that consumers 
receiving sales promotion on their mobile device express more positive feelings towards buying wine on mobile devices. The path online sales promotion and website loyalty, while statistically significant, offered minimal effect $(\beta=-.06, \mathrm{p}<.001)$. This finding suggests a negative effect of sales promotion on website loyalty. In other words, loyalty to winery websites decreases with the increase of sales promotions. The linkage between loyalty and sales promotion has been studied in various contexts and has produced mixed results. For example, there are studies that support the negative effect of sales promotion and loyalty (e.g. Hunt \& Keaveney, 1994; Yoo, Donthu, Lee, 2000) while other find positive effects (e.g. Oliver, 1977; Dick \& Basu, 1994; Krishnan, 1996).

The overall indirect (mediation) effect was tested using a bootstrap estimation approach with 1000 samples (Shrout \& Bolger, 2002). The results indicated the indirect coefficient was significant in our analysis. The indirect effect observed was for feelings towards buying wine $(\mathrm{X})$ on mobile phones via sales promotion (Mi) to m-commerce website loyalty (Y) $(\beta=-.01$, S.E. $=.03$, Boot LLCI $=-.02$, Boot ULCI $=-.01$ ). The results show that the direct effect of feelings towards buying wine on mobile phone and loyalty towards m-commerce websites in the presence of online sales promotion was not significant $(\beta=-.03, \mathrm{~S} . \mathrm{E}=.01, \mathrm{p}>.05)$. This result supports the mediational hypothesis and is consistent with full mediation (Baron and Kenny, 1997). We found that higher levels of website promotions are linked to lower likelihoods of website loyalty. This result is consistent with literature suggesting that sales promotion may harm brand equity (Allaham, 2015).

Table 3 about here

\subsection{Moderation - the role of online-service (wine delivery) attributes (H2)}

We followed Preacher et al. (2007) to establish moderation when testing Hypothesis 2 that importance of online service (wine delivery) attributes of the winery website moderates the relationship between feelings towards buying wine via mobile phone and $\mathrm{m}$-commerce website loyalty. After controlling for wine expertise and drinking habits, feelings toward buying wine on mobile phones and website loyalty was significant and positively related $(\beta=$ $.03, \mathrm{~S} . \mathrm{E}=.01, \mathrm{p}<.05)$ and the mediating factor online sales promotion and website loyalty was negatively related $(\beta=-.06$, S.E. $.01, \mathrm{p}<.001)$. The moderating variable online service (wine delivery) attributes and website loyalty was significant and positively related $(\beta=.15$, 
$\mathrm{S} . \mathrm{E}=.02, \mathrm{p}<.001)$. The interaction term for feelings towards buying wine on mobile phone with online service (wine delivery) attributes $(\beta=.09, \mathrm{~S} . \mathrm{E}=.02, \mathrm{p}<.001)$ was also significant in predicting website loyalty (See Table 4).

Table 4 about here

\subsection{Moderated mediation (H3)}

We followed Preacher et al's (2007) procedure to test a moderated-mediation model (a and b paths are both moderated by $\mathrm{W}$ ). Table 5 reports a special case when both the $\mathrm{a}_{1}$ (Feelings towards buying wine via mobile phone $\rightarrow$ Importance of Sales Promotions) and $b_{1}$ paths (Importance of Sales Promotions $\rightarrow$ Mobile website loyalty) of an otherwise simple mediation model are moderated by W (Online service (wine delivery) attributes of the winery website). This special case of moderated mediation is demonstrated by researchers (See Murray et al., 2003; Bauer et al., 2006; Muller et al., 2005). Hayes (2013) defines moderatedmediation when the indirect effect of $\mathrm{X}$ on $\mathrm{Y}$ through Mi is moderated by $\mathrm{W}$, this means that mediation of the effect of $\mathrm{X}$ on $\mathrm{Y}$ is moderated; a phenomenon called moderated mediation (p.389). Moderated mediation was assessed following Hayes (2013) to determine whether the strength of the mediation (sales promotion) differs across the levels of the moderator (service) in explaining the effect of feelings towards buying wine on mobile phones and website loyalty. Moderated mediation is demonstrated when the conditional direct effect of feelings towards buying wine on mobile phones and on website loyalty via sales promotion differ in strength across the values of the moderator (wine delivery service attributes). We operationalized high and low levels of online service attributes as one standard deviation above and below the mean score. Table 5 presents the estimates, standard errors, and significance value of the conditional direct effect of independent on dependent variable at values of the moderator.

Table 5 about here

Results show that online services such as wine delivery attributes moderate the mediation of online sales promotion between the positive feelings towards buying wine on mobile phone and m-commerce websites loyalty (H3). As additional observations, we see that the effect of feelings towards buying wine on mobile phones and m-commerce website loyalty is stronger 
when buyers receive higher levels of service from m-commerce websites (e.g. on-time delivery; quality of the wine; tracking your online purchase and low delivery charges).

Results also show that for online services and in particular wine delivery attributes, the conditional direct effects are at higher values of the moderator $(\beta=.11, \mathrm{~S} . \mathrm{E}=.02, p<.001)$ than at the mean score $(\beta=.03, \mathrm{~S} . \mathrm{E}=.02, p=.05)$. In other words, the role of sales promotions decreases when service delivery of the winery website increases. Taken together, results verify our observation that there is a moderated mediation. Specifically, feelings towards buying wine on mobile phones and on website loyalty via sales promotion differs in strength across the values of the moderator (wine delivery service attributes).

\section{CONCLUSIONS}

This paper examines a) the mediating role of sales promotion on the relationship between feelings towards buying wine through mobile phones and m-commerce website loyalty, and b) the moderating role of service attributes of $\mathrm{m}$-commerce websites in influencing the mediation. We found that sales promotional efforts mediate the relationship between positive feelings towards buying wine via mobile phone and $\mathrm{m}$-commerce website loyalty. Online service moderates the strength of the mediated relationship between positive feelings towards buying wine on mobile phone and $\mathrm{m}$-commerce websites loyalty via sales promotions. Our results shed further light onto these relationships. For example, positive feelings towards mobile wine buying and loyalty towards m-commerce websites are related to higher levels of online sales promotion. Results show that for online service such as wine delivery attributes, the conditional direct effects are at higher values of the moderator than at the mean score.

Taken together, results support our proposal that there is a moderated mediation between feelings towards buying wine on mobile phone and being loyal to the website selling wine (see Tables $3 \& 4$ ). This suggests promotional efforts are effective when service attributes are delivered moderating the likelihood of repeat purchase.

\subsection{Practical Implications}


The growing use of radio technology systems such as Beacon ${ }^{1}$ provide wine sellers with "push marketing" techniques that can be used to maximise loyalty assuming customer's delivery satisfaction standards are met. Push marketing, including mobile email, SMS, in-app and other push notifications, offer wine marketers the potential to reach customers with messages whenever and wherever they are, enabling further growth of m-commerce. As it is becoming increasingly difficult for wine brands, especially the small ones, to grab the attention of current and prospective customers, messages which solicit a call to action such as sales promotion must be delivered to customer's satisfaction.

The development and improvement of new technologies will make the mobile experience even more convenient in the future. However, wine is a specific commodity good where the associated services are important. On time delivery is crucial and associated services such as storing the wine in a proper place with the right temperature, hygrometry and luminosity conditions offer avenues to exceed expectations. This is especially the case for the luxury wines because the product should be perfect when consumed. Offering cellar condition information on websites should be a priority for m-commerce wine marketer strategy.

The results of the current study indicate a unique tension for wine marketers. While sales promotions can deliver increased purchasing (Chan et al., 2017) they run the risk of eroding customer loyalty, which over time will have impacts on word of mouth and customer referral behaviour. This tension indicates a delicate balancing act is needed to ensure that short-term gains form sales promotions do not erode profits in the longer term. A strategic emphasis on service delivery will yield greater effects in the long term given that effects are higher when higher service standards are perceived.

\subsection{Limitations of the research and recommendations for future research}

There are limitations of this research. The first limitation pertains to uneven distribution of samples across six countries and limitations associated with convenience sampling methods used by the research team. Thus, the results of this study are not generalizable. We

\footnotetext{
${ }^{1}$ Beacons transmit small amounts of data via Bluetooth Low Energy (BLE) up to 50 meters, and as a result are often used for indoor location technology, although beacons can be used outside as well.
} 
recommend future research employing a random sampling or stratified sampling approach to ensure demographic spread before definitive conclusions are drawn. Second, for the proposed moderated mediation, participants were classified as wine loyalist based on club memberships and/or "fan" pages, which may oversimply attitudinal predispositions held by consumers. Future research offering more nuanced assessments of attitudinal loyalty are recommended to further extend understanding. Feelings towards buying wine via mobile phone were generated from a review of the literature, limiting insights that could be gained in the current study. Additional research is recommended. In particular, qualitative methods are recommended to extend our understanding of emotional connections between consumers and wine for m-commerce. Additional research is recommended to examine group differences within countries and to undertake country comparisons to establish boundary conditions for the model. Future research could include other countries with growing wine consumption such as China (including Hong Kong and Taiwan), Singapore, Russia, Brazil and important European countries such as Italy.

This examination centred on m-commerce. Future empirical research is recommended in a wine e-commerce to extend understanding. M-commerce offers 24-7 wine marketer access to consumers extending marketer reach beyond what previously achievable when compared to traditional bricks and mortar retailing. Future research is recommended to examine attitudes towards wine purchasing behaviors, including differences between m-wine purchasers $v s$. non-purchasers, as well as differences across different age groups. It will be also interesting to compare results between subgroups and between countries. In addition, the measurement of feelings with the methodology PAD can be replaced by more sophisticated methods such as implicit measurement methods.

\section{References}

Allaham, M. (2015), The effect of Sales promotion tools on brand image, International Journal of Business and Management Invention, 4 (2), 52-58.

Bearden W., Netemeyer R., Haws K. (2010), Handbook of Marketing Scales: Multi-Item Measures for Marketing and Consumer Behavior Research, Sage Publications, Inc.

Bell, G., \& Dourish, P. (2007), "Yesterday's tomorrows: notes on ubiquitous computing's dominant vision", Personal and Ubiquitous Computing, Vol. 11 No. 2, pp. 133-143.

Bentler, P. M. (1992), EQS Structural Equation Program Manual, BMDP Statistical Software, Los Angeles.

Bressolles, G., Durrieu, F. and Giraud, M. (2007), “The impact of electronic service quality's dimensions on customer satisfaction and buying impulse", Journal of Customer Behaviour, Vol. 6 No. 1, pp. 37-56. 
Bruwer, J., and Thach L. (2013), Wine tourists' use of sources of information when visiting a USA wine region, Journal of Vacation Marketing, Vol. 19 No. 3, pp. 221-237

Chaudhuri, A. and Holbrook, M.B. (2001), "The chain of effects from brand trust and brand affect to brand performance: The role of brand loyalty", Journal of Marketing, Vol. 65 No. 2, pp. 81-93.

Chan, T.K.H., Cheung, C.M.K. and Lee, Z.W.Y. (2017), “The state of online impulse-buying research: A literature analysis," Information \& Management, Vol. 54 No. 2, pp. 204217.

Choi J., Seol H., Cho H. and Park, Y. (2008), "Customer satisfaction factors of mobile commerce in Korea", Internet Research, Vol. 18 No. 3, pp. 313-335.

Cronbach, L. J. (1951), "Coefficient alpha and the internal structure of tests", Psychometrika, Vol. 22 No. 3, pp. 297-334.

Cyr D., Bonanni C., Bowes J. and Ilsever J. (2006), "Beyond trust: web site design preferences across cultures", Journal of Global Information Management, Vol. 13 No. 4, pp. 25-52.

Davis, F.D. (1989), "Perceived Usefulness, Perceived Ease of Use, and User Acceptance of Information Technology", MIS Quarterly, Vol. 13 No. 3, pp. 319-340.

Dressler, M. (2016), Prosumers in the wine market: An explorative study. Wine Economics and Policy, Elsevier. Volume 5, Issue 1, pp. 24-32.

E-Marketer (2015), Commerce Snapshot: October 2015, available at www.emarketer.com (accessed 2 October 2015).

Engelhard, W., (2011), Wieder weniger weinkunden. Wein+Markt, ProWein Ausgabe 2011, pp. 14-15.

Eroglu, S. A., Machleit, K. A. and Davis L. M. (2001), "Atmospheric qualities of online retailing: a conceptual model and implications", Journal of Business Research Special issue on Retail Strategy and Consumer Decision Research, Vol. 54, November, pp. 177-184.

Flavian, C. and Guinaliu, M. (2006), "Consumer Trust, Perceived Security and Privacy Policy - Three Basic Elements of Loyalty to a Web Site", Industrial Management and Data Systems, Vol. 106 No. 5, pp. 601-620.

Gerbing D.W. and Anderson J.C. (1988), “An updated paradigm for scale development incorporating unidimensionality and its assessment", Journal of Marketing Research, Vol. 25 No. 2, pp. 186-192.

Ha, Y. W. and Park, M. C. (2013), "Antecedents of customer satisfaction and customer loyalty for emerging devices in the initial market of Korea: An equity framework", Psychology and Marketing, Vol. 30 No. 8, pp. 676-689.

Hair, J., Bush, R. and Ortinau, D. (2009), Marketing Research, McGraw-Hill Ltd, New York.

Hall C. Michael \& Prayag (2018), Call for papers, International Journal of Wine Business Research.

Higgins, L. M, Wolf, M.M., Bitter, R. and Amspacher, W. (2014), “Click Ship, Sip: Who is the Online Wine Buyer?" Proceedings of 8th International Conference of the Academy of Wine Business, Geisenheim, Germany, June 28-30, 2014.,

Huang, L., Lu, X. and Ba, S. (2015), "An empirical study of the cross-channel effects between web and mobile shopping channels", Information and Management, Vol. 53 No. 2, pp. 265-278.

Jungbauer F., (2012), Social media \& wein: ein erfolgsfaktor?, Der Dtsch. Weinbau, 24 (2012), pp. 22-24 
Kaikkonen, T. (2012), The role of online store atmospherics on consumer behaviour: Literature review. Unpublished research paper from Aalto School of Economics, pp. 1-27.

Kaur, H. and Soch, H. (2013), "Mediating roles of commitment and corporate image in the formation of customer loyalty", Journal of Indian Business Research, Vol. 5 No. 1, pp. $33-51$.

Koufaris, M. (2002), “Applying the technology acceptance model and flow theory to online consumer behavior”, Infomation System Research, Vol. 13 No. 2, pp. 205-224.

Lee, D., Moon, J., Kim, Y. J. and Mun, Y. Y. (2015), “Antecedents and consequences of mobile phone usability: Linking simplicity and interactivity to satisfaction, trust, and brand loyalty", Information and Management, Vol. 52 No. 3, pp. 295-304.

Leeflang, P. S., Verhoef, P. C., Dahlström, P. and Freundt, T. (2014), "Challenges and solutions for marketing in a digital era", European Management Journal, Vol. 32 No. 1, pp. 1-12.

Lenhart A., Purcell K., Smith A. and Zickuhr K. (2011), Social Media and Young Adults, Pew Internet and American Life Project (2011), Pew Research Center, available at http://www.pewinternet.org/Reports/2010/Social-Media-and-Young-Adults.aspx (accessed September 2016)

Li, M., Dong, Z.Y. and Chen, X. (2012), "Factors influencing consumption experience of mobile commerce: a study from experiential view”, Internet Research, Vol. 22 No. 2 , pp. 120-141.

Lin, H.H. and Wang, Y.S. (2006), "An examination of the determinants of customer loyalty in mobile commerce contexts", Information and Management, Vol. 43 No. 3, pp. 271282.

Lobstein, T., Landon, J., Thornton, N., and Jernigan, D. (2017), "The commercial use of digital media to market alcohol products: a narrative review", Addiction, Vol. 112, pp. 21-27.

Masters J. and Wyndol F. (1976), "Effects of Affective States on Noncontingent Outcome Expectancies and Beliefs in Internal or External Control", Developmental Psychology, Vol. 12 No. 5, pp. 481-82.

Mehrabian A. and Russell J.A. (1974), An approach to environmental psychology, The MIT Press, Cambridge, MA

Okazaki, S. (2010), "Determinant Factors of Mobile-Based-Word-of-Mouth Campaign Referral among Japanes Adolescents", Psychology and Marketing, Vol. 25 No. 8, pp. 714-731.

Osuna Ramírez, S.A., Veloutsou, C. and Morgan-Thomas, A. (2017), “A Systematic Literature Review of Brand Commitment: Definitions, Perspectives and Dimensions", Athens Journal of Business and Economics, (Early Online Publication). Available online at http://eprints.gla.ac.uk/139423/.

Parasuraman, A., Zeithaml, V. and Malhotra, A., (2005), "E-S-QUAL: a multiple-item scale for assessing electronic service quality", Journal of Retailing, Vol. 64 No. 1, pp. 12-40.

Pelet J.-É. and Lecat B. (2014), "Smartphones and wine consumers: A Study of Gen-Y", International Journal of Wine Business Research, Vol. 26 No. 3, pp.188 - 207.

Pelet J.-É., Lecat B., Khan J., Lee L.W., Vigar-Ellis D., Mc Garry Wolf M., Rundle-Thiele S., Kavoura N. Katsoni V. and Wegmann A.-L. (2015), Wine and website loyalty: a model of sales promotion and service attributes, $9^{\text {th }}$ Academy of Wine Business Research (AWBR) Conference, University of South Australia in Adelaide, Australia, 17-19 February 2016. 
Pelet J.-É., Lecat B., Taieb B., Terbkanche N. and Wayes V. (2016), Optimizing the supply chain of wine with social media and collaborative consumption, 2nd edition of the International Conference PROLOG "Project and Logistic" Agadir, 5-6 May, 2016.

Peng, J., Zhang, G., Zhang, S., Dai, X. and Li, J. (2014), "Effects of Online Advertising on Automobile Sales", Management Decision, Vol. 52 No. 5, pp. 2-2.

Preacher, K. J., Rucker, D. D. and Hayes, A. F. (2007), "Addressing moderated mediation hypotheses: Theory, methods and prescriptions", Multivariate Behavioural Research, Vol. 42 No. 1, pp. 185-227.

Rossiter, J. R. (2002), "The C-OAR-SE procedure for scale development in marketing", International Journal of Research in Marketing, Vol. 19 No. 4, 305-335.

Rundle-Thiele, S.R. (2005), "Elaborating customer loyalty: Exploring loyalty to wine retailers." Journal of Retailing and Consumer Services, Vol. 12 No. 5, 333-344.

Schipperges M. (2013), Verbraucher offen für neue entdeckungen, Das Dtsch. Weinmagazin, $17-18$, pp. 58-63

Shaikh, A.A. and Gupta, G.K. (2014), "M-Commerce recommendation with mobile cloud architecture", International Journal of Application or Innovation in Engineering and Management, Vol. 3 No. 11, pp. 347-352.

Sørensen, J. (2008), Measuring emotions in a consumer decision-making context approaching or avoiding, Working paper, Department of Business Studies, Aalborg University, Denmark.

Statista (2016), Global mobile payment transaction volume from 2015 to 2019 (in billion U.S. dollars), available at http://www.statista.com/statistics/226530/mobile-paymenttransaction-volume-forecast/ (accessed 20 May 2016).

Thach, L., Olsen, J. and Lease, T. (2014), Selling Wine Online: Which Winery Ecommerce Practices Promote Highest Sales? available at http://www.winebusiness.com/news/?go=getArticle\&dataid=13979 (accessed 15 August 2015).

Trevinal, A.M. and Stenger, T. (2014), "Toward a conceptualization of the online shopping experience”, Journal of Retailing and Consumer Services, Vol. 21 No. 3, pp. 314-326.

Trent, J. and Bastian, S. (2007), a preliminary study of the relationship between Australian wine consumers' wine expertise and their wine purchasing and consumption behaviour, Australian Journal of Grape and Wine Research. 13(3):186-197.

Tubaro, P., Casilli, A.A. and Sarabi, Y. (2012), Réseaux sociaux : Vers la fin de la vie privée ? CIGREF foundation, available at: http://www.fondation-cigref.org/reseaux-sociauxvers-la-fin-de-la-vie-privee/ (accessed July 2016).

Valdez, P. and Mehrabian, A. (1994), "Effects of Color on Emotions", Journal of Experimental Psychology: General, Vol. 123 No. 4, pp. 394-409.

Wu C.-S., Cheng F.-F. and Yen D.C. (2008), "The atmospheric factors of online storefront environment design: an empirical experiment in Taiwan", Information and Management, Vol. 45 No. 7, pp. 493-498.

Wu, J. H. and Wang, S. C. (2005), "What drives mobile commerce?: An empirical evaluation of the revised technology acceptance model", Information and management, Vol. 42 No. 5, pp. 719-729.

Yoon, S. (2002), "The antecedents and consequences of trust in online purchase decisions", Journal of Interactive Marketing, Vol. 16 No. 2, pp. 47-63.

Yoon, D., Choi, S. M. and Sohn, D. (2008), "Building customer relationships in an electronic age: The role of interactivity of e-commerce websites", Psychology and Marketing, Vol. 25 No. 7, pp. 602-618. 




Research Model

$21 \times 10 \mathrm{~mm}(150 \times 150 \mathrm{DPI})$ 


\section{TABLES}

Table 1: Internal consistency assessment

\begin{tabular}{|c|c|c|c|c|c|c|c|}
\hline Factors & Cronbach $\alpha$ & Mean & S.D. & $\mathbf{Y}$ & Mi & $\mathbf{X}$ & $\mathbf{W}$ \\
\hline $\mathbf{X}$ & .71 & 3.7 & .70 & 1 & & & \\
\hline Mi & .70 & 2.7 & 1.0 & $-.04 *$ & 1 & & \\
\hline $\mathbf{X}$ & .89 & 2.8 & .92 & $.06 * *$ & $.15 * *$ & 1 & \\
\hline $\mathbf{W}$ & .69 & 3.8 & .84 & $.14 * *$ & $.27 * *$ & $.15^{* *}$ & 1 \\
\hline \multicolumn{8}{|c|}{ Note: ** Correlations are significant at the 0.01 level (2-tailed). } \\
\hline $\mathrm{X}$ & \multicolumn{7}{|c|}{$=$ Feelings towards buying wine on mobile phone } \\
\hline Y & \multicolumn{7}{|c|}{$=$ Mobile website loyalty } \\
\hline Mi & \multicolumn{7}{|c|}{$=$ Importance of Sales Promotions } \\
\hline W & \multicolumn{7}{|c|}{$=$ Service (wine delivery) attributes of the website } \\
\hline
\end{tabular}

Table 2: Results of construct validity

\begin{tabular}{lccccccc}
\hline & CR & AVE & MSV & ASV & W & X & Mi \\
\hline W & 0.70 & 0.35 & 0.17 & 0.10 & $\mathbf{0 . 5 9}$ & & \\
$\mathbf{X}$ & 0.90 & 0.63 & 0.04 & 0.03 & 0.19 & $\mathbf{0 . 8 0}$ & \\
$\mathbf{M i}$ & 0.60 & 0.47 & 0.17 & 0.10 & 0.41 & 0.18 & $\mathbf{0 . 6 6}$
\end{tabular}

Note: *Factor correlations and discriminant validity (square root of average variance extracted displayed on the diagonal).

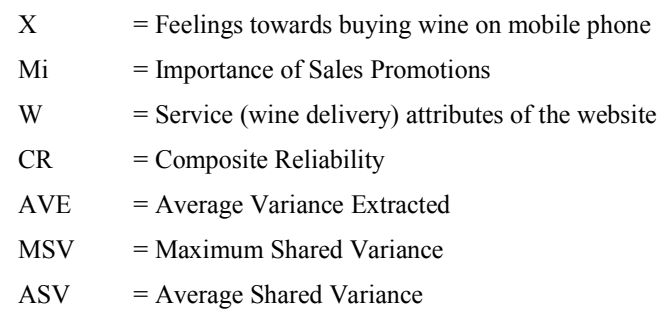

Table 3: Results for testing of mediation $\mathrm{H1}$

\begin{tabular}{|c|c|c|c|}
\hline $\mathbf{I V} \downarrow$ & DV: Mi & DV: Y & $0 \times$ \\
\hline $\mathbf{X}$ & $.17^{* * *}(.02)$ & $.03^{\mathrm{NS}}(.01)$ & $\bar{C}$ \\
\hline Mi & & $-.06^{* * *}(.01)$ & \\
\hline HABIT & & $.01^{\mathrm{NS}}(.01)$ & \\
\hline EXPERT & & $.02^{\mathrm{NS}}(.02)$ & \\
\hline $\mathbf{R}^{2}$ & .16 & .20 & \\
\hline $\mathbf{F}$ & $21.30^{* * *}$ & $18.79^{* * *}$ & \\
\hline
\end{tabular}


Level of confidence for all confidence intervals in output: 95.00

Y

$=$ Website loyalty

$\mathrm{X}$

$=$ Online sales promotion

HABIT

$=$ Feelings towards buying wine on mobile phone

EXPERT

$=$ Glass of wine consumption per week

$=$ Knowledge and experience of wine

Table 4: Results for testing of moderation $\mathrm{H} 2$

\begin{tabular}{llll}
\hline IV $\downarrow$ & DV: LOY & LLCI & ULCI \\
\hline FMOB & $.03^{*}(.01)$ & .01 & .06 \\
PROM & $-.06^{* * *}(.01)$ & -.08 & -.03 \\
SERV & $.15^{* * *}(.02)$ & .12 & .19 \\
FMOB X SERV & $.09^{* * *}(.02)$ & .06 & .13 \\
HABIT & $.01^{\mathrm{NS}}(.01)$ & -.02 & .03 \\
EXPERT & $.02^{\mathrm{NS}}(.02)$ & -.05 & .05 \\
$\mathbf{R}^{\mathbf{2}}$ & .20 & & \\
F & $18.79^{* * *}$ & & \\
\hline
\end{tabular}

Note: ${ }^{* * *} \mathrm{p}<.001,{ }^{* *} \mathrm{p}<.01,{ }^{*} \mathrm{p}<.05, \mathrm{NS} \mathrm{p}>.05$

Number of bootstrap samples for bias corrected bootstrap confidence intervals: $\quad 1000$

Level of confidence for all confidence intervals in output: 95.00

LOY

$=$ Website loyalty

PROM

$=$ Online sales promotion

FMOB $\quad=$ Feelings towards buying wine on mobile phone

HABIT $\quad=$ Glass of wine consumption per week

EXPERT $\quad=$ Knowledge and experience of wine

SERV = online-service (wine delivery) attributes

Table 5: Moderated mediation result for sales promotion and online (wine delivery) service H3

\begin{tabular}{lclcccc}
\hline Moderator & Level & $\begin{array}{l}\text { Conditional } \\
\text { direct effect }\end{array}$ & SE & Sig & LLCI & ULCI \\
& & & & & \\
\hline Online service & -.84 & -.05 & .02 & .03 & -.09 & -.01 \\
(wine delivery) & .00 & .03 & .02 & .05 & .00 & .06 \\
attributes & .84 & .11 & .02 & .00 & .07 & .15 \\
\hline
\end{tabular}

